Studia Ceranea 3, 2013, p. 177-185

Krzysztof Tomasz Witczak (Łódź)

\title{
HYSTRIX IN GREEK
}

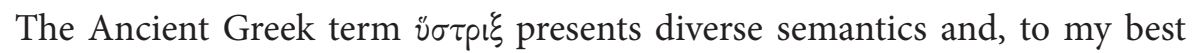
knowledge, it demonstrates seven different meanings:

I. (usually used in the plural) 'swine bristle'. This meaning is undoubtedly

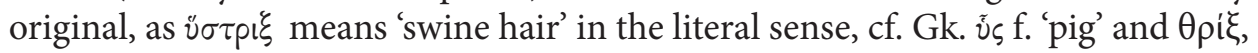
gen. sg. тpıós m. 'hair').

II. 'swine leather whip, the cat, used as an instrument of punishment'.

III. 'porcupine, Hystrix cristata' as a Libyan animal.

IV. 'hedgehog, Erinaceus europaeus L.'

V. 'sea urchin (class Echinoidea)'.

VI. 'badger, Meles meles L.' (exclusively in the Ionic dialect).

VII. 'an unclearly defined, animal'.

The available Ancient Greek dictionaries register only some of these meanings. The four-volume Ancient Greek-Polish dictionary has only two meanings: III

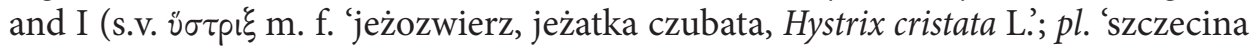

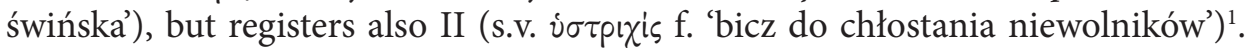
These same meanings are given by Oktawiusz Jurewicz ${ }^{2}$. The authors of the GreekPolish dictionaries generally follow the well-known Greek-English Lexicon LSJ, where the same three meanings (III, I, II) appear in the same order ${ }^{3}$. Only one meaning (III) is given in Dvorecky's two-volume Ancient Greek-Russian dictionary ${ }^{4}$. The Greek-German lexica demonstrate a twofold meaning 'hedgehog, porcupine / Igel, Stachelschwein' (IV+III), as well as the sense 'Stachelpeitsche' (II) for the appellative $\dot{\sigma} \tau \tau_{p} x^{\prime} \varsigma^{5}$. In his Vocabulario della lingua greca Franco Montanari has two meanings (III 'porcopino, istrice'; I 'setole'), but he introduces the third meaning

\footnotetext{
1 Stownik grecko-polski, ed. Z. Abramowiczówna, vol. IV, Warszawa 1965, p. 479.

2 Stownik grecko-polski, ed. O. JuRewICZ, vol. II, Warszawa 2001, p. 458.

3 A Greek-English Lexicon, ed. H.G. Liddell, R. Scott, H.S. JonEs, with a revised supplement, ${ }^{9} \mathrm{Ox}-$ ford 1996, p. 1906.

4 Древнегреческо-русский словарь, ed. И.Х. Дворецкий, vol. II (M- $\Omega)$, Москва 1958, p. 1706, s.v. ข้ $\tau р \xi$ ('porcupine / дикобраз, Hystrix cristata').

5 See Menge-Güthling Griechisch-deutsches und deutsch-griechisches Wörterbuch mit besonderer Berücksichtigung der Etymologie, vol. I, Griechisch-deutsch, ed. H. MENGE, ${ }^{2}$ Berlin-Schönberg 1913, p. 718 ('Igel, Stachelschwein'); W. Gemoll, Griechisch-Deutsches Schul- und Handwörterbuch, Wien-Leipzig 1908,

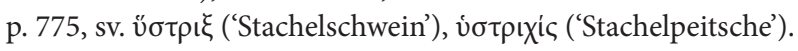


(II) in the next entry: $\dot{\sigma \tau p l x i s ~-~ ' f r u s t a ~(p e r ~ p u n i r e ~ g l i ~ s c h i a v i) ' ; ~ m e d . ~ ' m a l l a t i a ~ a l l a ~}$ coda dei cavalli'. Thus it is necessary to review anew the semantics of the Greek word $\tilde{\sigma \tau \tau \rho \xi} \xi$.

Ad I. The etymological meaning 'swine bristle' (usually in the plural, v์ $\tau \tau\llcorner\chi \varepsilon \varsigma$ ) seems to be attested securely in a comedy by Plato the Younger?. The comedy in question is not preserved, but the relevant fragment is quoted by Clement of Alexandria:

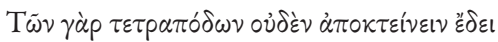

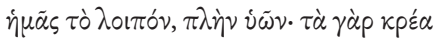

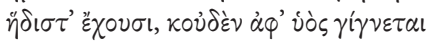

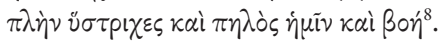

In his play Feasts Plato, the comedist, says truly suitable words:

Among the quadrupeds no animal has

to be killed by us, except pigs, because pigs have

very tasty meat, and alive pig gives us nothing

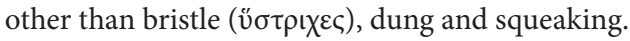

Ad II. The most certain attestation for the second meaning derives from the so-

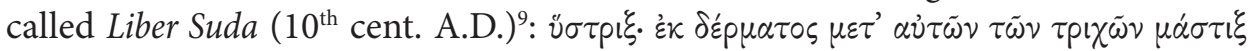
[...] Hystrix - whip made of leather together with the hair [my translation - K.T.W.].

The whip made from pig's leather and bristle was alternatively called $i \sigma \tau p i x i s$ in the Attic dialect.

Ad III. Herodotus ${ }^{10}$ and Claudius Aelian ${ }^{11}$ speak clearly about the Libyan fauna, thus the meaning 'crested porcupine, Hystrix cristata L.' seems relatively certain. Herodotus mentions $\tilde{\sigma} \sigma \tau \not \chi \varepsilon \varsigma$ in a long list of the exotic animals of Libya:

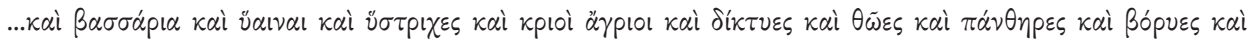

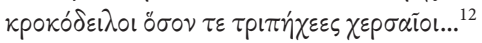

...foxes, hyenas, porcupines, wild rams, the dictys, jackals, panthers, the borys, land crocodiles three cubits long...

6 F. Montanari, Vocabulario della lingua greca, Milano 2003, p. 2122.

7 Plato, Com., fr. 28, See Supplementum comicum, ed. J. Demiańczuk, Kraków 1912, p. 76-82.

8 Clemens Alexandrinus, Stromata, VII, 6, [in:] idem, Stromata Buch VII und VIII, Excerpta ex Theodoto, Eclogae propheticae, Quis dives salvetur, Fragmente, ed. O. StÄhlin, L. Früchtel, U. Treu, vol. II, Berlin 1970 (cetera: Clemens Alexandrinus) [= GCS, 17]. English translation of the passage by the author of the article.

9 Suidae Lexicon, Y, 692, rec. A. AdLer, vol. IV, Lipsiae 1935 [repr. 1971] (cetera: Suda), p. 684

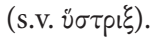

${ }^{10}$ Herodoti Historiae, IV, 192, ed. H.B. Rosén, vol. I, Leipzig 1987 (cetera: Herodotus).

11 Aelian, On the Characteristics of Animals, XII, 26, trans. A.F. Scholfield, vol. III, London-Cambridge Mass. 1959 (cetera: Aelian).

12 Herodotus, IV, 192; trans. A.D. Godley, vol. II, Books III and IV, London-Cambridge Mass. 1957, p. 395. Jeżatki 'atherurus porcupine' in the Polish translation of the passage (Herodot, Dzieje, trans.

S. HAMmer, ${ }^{2}$ Warszawa 1959, vol. I, p. 343). 
Aelian's description of $๊ \sigma \tau p \downarrow \xi$, though obviously lacking scientific precision, refers to the porcupine:

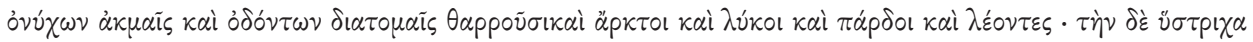

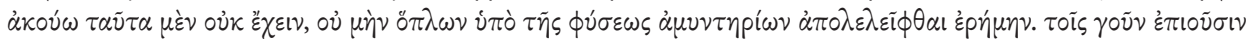

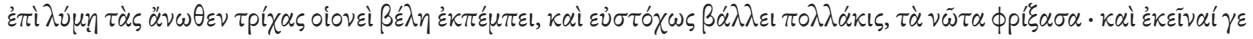

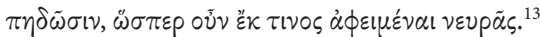

Strength of claws and sharpness of fangs make bears, wolves, leopards, and lions bold, whereas the porcupine, which (I am told) has not these advantages, none the less has not been left by Nature destitute of weapons wherewith to defend itself. For instance, against those who would attack it with intent to harm it discharges the hairs on the body, like javelins, and raising the bristles on its back, frequently makes a good shot. And these hairs leap forth as though sped from a bowstring.

In his different account on a similar subject the animals in question are called

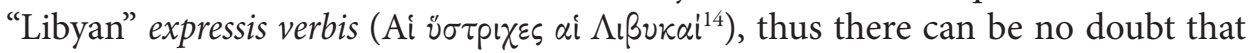
the identification of Aelian's $\check{\sigma} \sigma p \iota x \varepsilon \varsigma$ as porcupines is correct.

Also Aristotle, referring to a work by Democritus of Abdera (fr. 150), seems to mean porcupines, as is to be seen in his text:

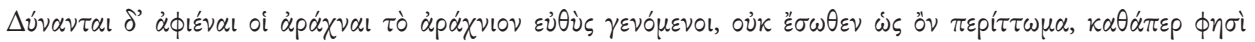

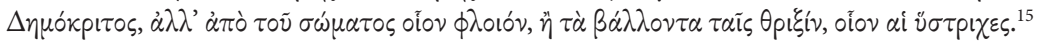

Spiders have the power of emitting their web as soon as they are born, not from within their bodies, as if it were an excrement, as Democritus says, but from the surface of their body, like the bark of a tree, or like the ejected spines of some animals, as the porcupin.$^{16}$

The Polish translator Paweł Siwek has jeże (pl. 'hedgehogs') in his rendition of Aristotle's work ${ }^{17}$. However, Aristotle says that vँ $\tau \tau$ i $\chi \varepsilon \varsigma$ belong to animals which throw off their hair ( $\tau \dot{\alpha} \beta \dot{\alpha} \lambda \lambda \lambda_{0 \nu \tau \alpha} \tau \alpha \tilde{i} \varsigma \theta p(\xi \dot{\xi}(v)$, thus the passage refers to porcupines rather than to hedgehogs.

Ad IV. The fourth meaning ('hedgehog, Erinaceus europaeus L.'), as well as the second one, can be safely established on the basis of the aforementioned entry in Liber Suda:

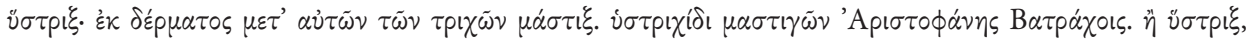

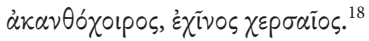

13 Aelian, I, 31, vol. I, London-Cambridge Mass. 1958, p. 49-51 (trans. A.F. Scholfield). Jeżozwierz 'porcupine' in the Polish translation of the passage (Klaudiusz Elian, $O$ właściwościach zwierząt (wybór), trans. A.M. KomorNickA, Warszawa 2005, p. 34).

14 Aelian, XII, 26.

15 Aristote, Histoire des animaux, IX, 39, ed. et trans. P. Louis (cetera: Aristoteles, HA), vol. III, Paris 1969.

16 Aristotle's History of Animals in ten books, trans. R. Cresswell, London 1883 (cetera: Aristotle's History), p. 260.

17 Arystoteles, Zoologia (Historia Animalium), trans. P. SiweK, Warszawa 1982, p. 414.

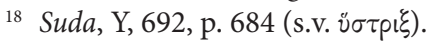


Hystrix - a whip made of leather together with the hair. 'Flogging with the whip' - thus Aristophanes in his Frogs. Or hystrix - "prickly pig", the earthen hedgehog.

The same meaning can be easily inferred from a list of synonyms for 'hedgehog' in Liber Suda:

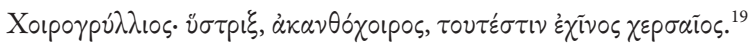

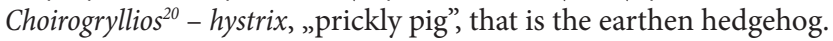

It should be emphasized that the meaning 'hedgehog, Erinaceus Europaeus L'. cannot be a late innovation of the Greek language (Liber Suda dates back to the $10^{\text {th }}$ cent. A.D.), as it may be attested as early as in Aristotle's times ( $4^{\text {th }}$ cent. B.C.). The Greek scholar from Stagira, talking about animals which hibernate, gives the following information:

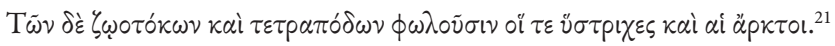

Among viviparous quadrupeds the porcupines [sic!] and bears hybernate.

It is obvious that this passage cannot refer to porcupines, which live in the warm zone of the Mediterranean area and never have to hibernate. This fragment may describe only hedgehogs or alternatively badgers (see my discussion below, ad VI).

Another passage by Aristotle seems more problematic. The text runs as follows:

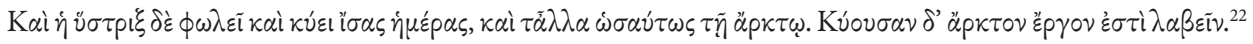
The female porcupine also hides away for the winter, and is pregnant for the same length of time, and otherwise does as the she-bear. It is no easy business to catch a bear when pregnant.

Aristotle informs us that the pregnancy of the female hystrix ( $\dot{\eta}$ $\sigma \tau \tau p ı)$ lasts as long as the pregnancy of the she-bear (ca. 8-9 months). This feature cannot refer to the female hedgehog, which pregnancy is relatively short (slightly over 1

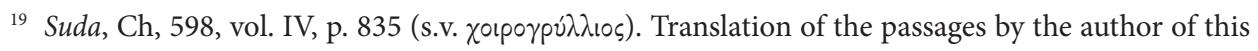
article.

${ }^{20}$ Greek $\chi 01 p \circ \gamma p u ́ \lambda \lambda$ เo seems to denote 'east rock hyrax, Procavia capensis syriacus Schreber', a medium-sized terrestrial animal, living in the Middle East and Africa. It has short ears and tail, resembling a guinea pig (Cavia porcellus L.). In antiquity the rock hyrax was compared with hedgehog, young hare and rabbit. See e.g. D. Duncan, Urchin, coney, rock badger - genus hopping with the choirogrullios, Dand 1, 2010, p. 1-4, http://dandelionjournal.org/index.php/dandelion/article/viewFile/3/45 [25 X 2013]. ${ }_{21}$ Aristoteles, HA, VIII, 17 [600a]; Aristotle's History, p. 215 (trans. R. Cresswell). Jeże (pl. 'hedgehogs') in the Polish translation of the text (Arystoteles, Zoologia..., p. 340).

22 Aristoteles, HA, VI, 30 [579a], vol. II, Paris 1968; Aristotle, Historia Animalium, trans. A.L. Peck, vol. II, London-Cambridge Mass. 1970 (cetera: Aristotle), p. 339. Consistently, samica jeża ('female hedgehog') in the Polish translation of this passage also (Arystoteles, Zoologia..., p. 275). 
month ${ }^{23}$ ). The female porcupine should be excluded for the same reason (ca. 2 to 3 and a half months) ${ }^{24}$. On the other hand, Aristotle's description of the hystrix (both the hibernation and the long gestation) seem to square very well with habits of the badger.

It is worth emphasizing that at least at one place Aristotle distinguishes be-

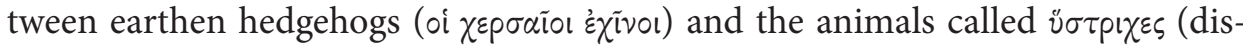
cussed below) ${ }^{25}$. In this place, $\tilde{\sigma} \sigma \tau p \chi \varepsilon \varsigma$ seem to refer to some maritime animals (see meaning V). However, meaning III 'porcupine' cannot be completely excluded.

Ad V. In the glossary written by Hesychius of Alexandria $\left(5^{\text {th }}\right.$ or $6^{\text {th }}$ cent. A.D.) we find the following gloss:

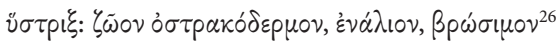

Hystrix - a hard-shelled animal, maritime, edible.

The same meaning suggests itself in a passage by Aristotle in Historia animalium:

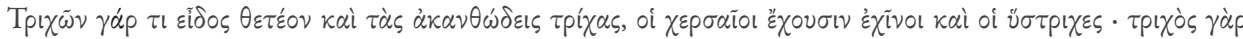

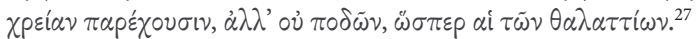

Nevertheless, all animals which have hair are viviparous (and we must include here as a kind of hair the spiny hairs of hedgehogs and porcupines: these spines serve the purpose of hair, and not of feet as do spines of the sea-urchin).

Ad VI. The meaning 'badger, Meles meles L.' for ü $\tau \tau p ı \xi$ is not evidently attested in the ancient sources for one important reason. Namely, we know no certainly established Ancient Greek term for 'badger' ${ }^{28}$. I believe, however, that there are

${ }^{23}$ L. Sykes, J. Durrant, The Natural Hedgehog, London 2005, p. 25: The gestation period is generally between 30 and 40 days. The same statement is posited by M. Burton, Guide to the Mammals of Britain and Europe, London 1985, p. 70 (Gestation 30-40 days). Differently L.J. DoBroruKA, Mammals, Leicester 1998, p. 40, who says: The gestation period is 5-6 weeks.

${ }^{24}$ L.J. Dobroruka, op. cit., p. 108, gives the following information regarding the porcupine: No exact data are available on the duration of pregnancy: the shortest estimates are 65 days, the longest 112 days. A similar approximation is given by M. BURTON, op. cit., p. 214: gestation 63-112 days.

${ }_{25}$ Aristoteles, HA, I, 6 [490b], vol. I, Paris 1964.

${ }^{26}$ Hesychii Alexandrini Lexicon, post I. Albertum rec. M. Schmidt, vol. IV, pars I, Ienae 1862 [repr.

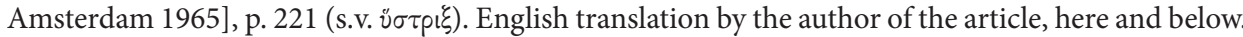

27 Aristoteles, HA, I, 6 [490b]; Aristotle, vol. I, trans. A.L. Peck, London-Cambridge Mass. 1965, p. 33. Jeże lądowe and jeże morskie ('land hedgehogs' and 'sea hedgehogs') in Arystoteles, Zoologia..., p. 18.

28 As far as I know, the following Greek terms can be surmised to denote the 'European badger, Meles

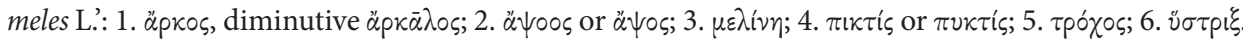
It should be emphasized that the first form «pros m. 'badger' (< Proto-Greek ${ }^{*}$ Fápros) was commonly

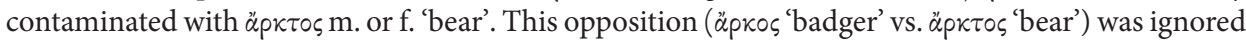
by scholars also in modern times. 
at least three premises, that allow us to suggest the meaning in question for Ancient Greek ข้ $\sigma p 1 \xi$.

Firstly, Modern Greeks from the Pontic area refer to the badger by means of the term $\xi \cup \sigma \tau i \gamma \kappa \iota$ [pronounced: xistrígi] ('Dachs'), which evidently derives from ${ }^{*} \partial \xi \nu-v \sigma \tau \tau \xi^{29}$. It follows that the term $\tilde{\sigma} \sigma \tau p \xi \xi$ could also denote the badger in antiquity, at least in the Ionic linguistic area (it is well known that the Modern Greek dialects of the Pontic area demonstrate features typical of Ionic, e.g. they preserves the long vowel $\eta$ with the value $[\mathrm{e}]$ ).

Secondly, the suggested semantics can be deduced from the Hesychian gloss:

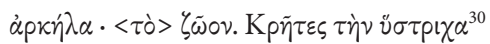

arkela - an animal; [thus] the Cretans [call] the badger (hystrix)

The meaning 'badger' is guaranteed by the Modern Greek (dial. Cretan)

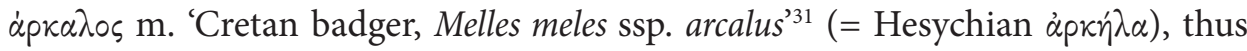
ข๊ $\tau p ı \xi$ in the Hesychian glossary can denote nothing other than 'badger'. The meaning 'porcupine' is completely excluded, for this animal did not (and does not) live in Crete. The remaining semantems IV ('hedgehog') and V ('maritime animal') are theoretically possible, but they, as well as 'porcupine', introduce semantic confusion and they explain nothing.

Thirdly, Eurasian badgers have their hair that is similar to swine bristle, from which brushes were and are made; thus the possible meaning 'having hair similar

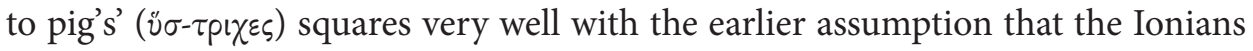
called the badgers $v^{\sigma} \sigma \tau i \chi \varepsilon \varsigma^{32}$.

The suggested hypothesis (Ionic $v^{\sigma} \sigma \tau p \xi \xi$ denotes 'badger' and not 'porcupine' ${ }^{\text {'33) }}$ remains in full agreement with the observed facts. The Hesychian gloss contains the word $\dot{\alpha} p k \eta \dot{\lambda} \alpha$ in the Ionic form containing the long vowel $\eta$ (cf. Doric $\bar{\alpha}$, con-

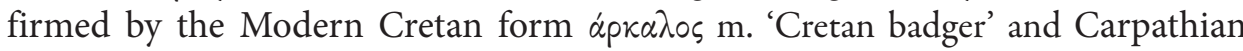
$\alpha$ p $\alpha \alpha \lambda \lambda$ os $\mathrm{m}$. 'young of the wild animals, esp. of bear, lion or leopard'34), as well as

29 See N. Andriotis, Lexikon der Archaismen in neugriechischen Dialekten, Wien 1974, p. 411, No. 4427 [= Schriften der Balkankommission. Linguistische Abteilung, 22].

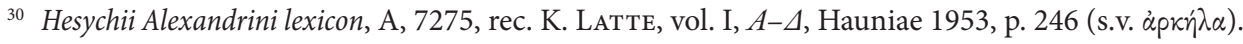

${ }^{31}$ N. Andriotis, Lexikon..., p. 153, No. 1164; G.P. Shipp, Modern Greek Evidence for the Ancient Greek Vocabulary, Sydney 1979, p. 95.

32 E. Kaczyńska, K.T. Witczak, Remarks on Some Doric Elements in the Modern Greek Dialects of Crete, E 92(1), 2005, p. 113-114; IIDEM, Mustelidae in the Cretan Dialect of Modern Greek, E 94, 2007, p. 298-302.

33 The confusion of 'badger' and 'porcupine' in Modern Greek is also known. G.P. SHIPP, op. cit., p. 96, gives the following comments to the Hesychian gloss in question: This entry must be brought into

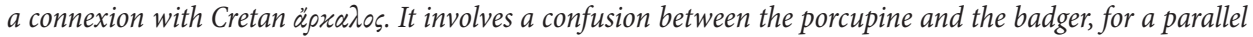
to which we need go no further than to ä $\sigma \beta$ ós, which in Macedonia is 'porcupine'. Hesych [ius] will then be citing the word in the corresponding Attic-Ionic form, presumably the name of another animal, then giving the Cretan meaning simply.

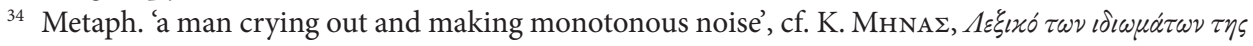

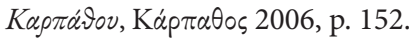




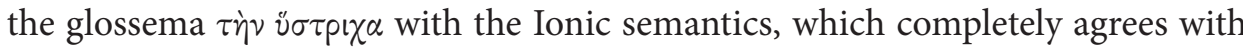
the Modern Cretan meaning ('badger').

What is more, at least two of Aristotle's texts are easier explained if one posits the suggested semantics 'badger' for the term $v^{\prime} \tau \tau p$. . The above-mentioned text by Aristotle is worth quoting once more:

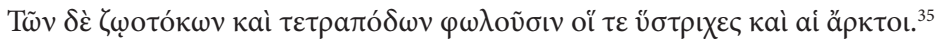
Among viviparous quadrupeds the porcupines and bears hibernate.

It is obvious that this passage cannot refer to porcupines, which live in the warm zone of the Mediterranean area and never have to hibernate. This fragment may only refer to hedgehogs or badgers.

As has been previously said, the crucial passage in the History of Animals was not understood properly:

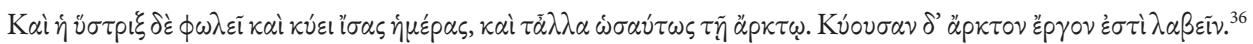
The female porcupine $(\dot{\eta} \cup \tau \tau p \mid \xi)$ also hides away for the winter, and is pregnant for the same length of time, and otherwise does as the she-bear. It is no easy business to catch a bear when pregnant.

Aristotle's information on the pregnancy of the female hystrix ( $\dot{\eta} \cup \tau \tau p \xi \xi)$, which is said to last as long as the pregnancy of the she-bear, can denote neither 'porcupine' nor 'hedgehog', as it refers to the female badger, whose pregnancy may be restrained for some months due to the so-called delayed implantation ${ }^{37}$. Most researchers agree that the duration of the badger's pregnancy varies between 7 months and 13-15 months ${ }^{38}$. In other words, it can be compared with the duration of a bear's pregnancy (ca. 8-9 months).

In his works devoted to zoological topics Aristotle seems to confuse the two meanings 'porcupine' (most popular) and 'badger' (local use, probably in Ionia). Such a semantic dispersion is also observed in Modern Greek. The word da $\sigma \beta_{\text {ós }}$ generally means 'badger', but in some areas (in Macedonia) it denotes the porcupine.

VII. The semantics 'an unidentifiable, or unclearly defined, animal' must be assumed in those cases, where the context provides no additional information

\footnotetext{
35 Aristoteles, HA, VIII, 17 [600a], vol. III; Aristotle's History, p. 215 (trans. R. Cresswell).

36 Aristoteles, HA, VI, 30 [579a], vol. II; Aristotle, trans. A.L. Peck, vol. II, p. 339.

37 M. Burton, op. cit., p. 114. The author explains it as follows: Mating usually in July but may occur February to October. Cubs born January to May. Does not mean gestation of 7 months as there is delayed implantation. Embryo is only implanted in wall of uterus 7-8 weeks before actual birth and then development proceeds normally. L.J. DoBRoRUKA, op. cit., p. 74, says that In some females latent pregnancy (i.e. temporarily suspended development of the embryo) has been observed, in others the development of the embryo proceeds without interruption. Gestation periods thus vary widely, between 7 and 15 months.

${ }_{38}$ P. SumiŃski, Borsuk, Warszawa 1989, p. 88: Wszyscy autorzy są zgodni, że ciąża trwa nie krócej niż 7 miesięcy, a może trwać nawet 13-15 miesięcy.
} 
as to whether the term $v_{\sigma \tau} \tau \xi \xi$ refers to the porcupine (III), the hedgehog (IV), or the badger (VI). It is necessary to include here the following examples:

A fragment by Aeschylus, the famous Athenian writer from the $6^{\text {th }}-5^{\text {th }}$ cent. B.C., is reconstructed on the basis of the works of Aristophanes of Byzantium, the Greek grammarian, and Aelian. Modern editors give the following text:

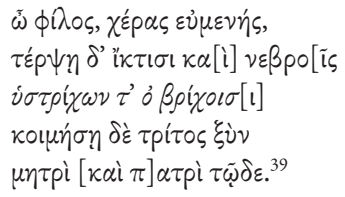

In the same place Aelian adds that the name in question was also used by the Athenian tragic poets:

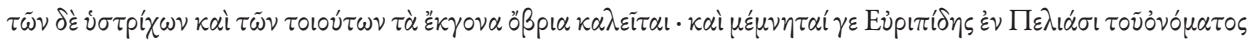

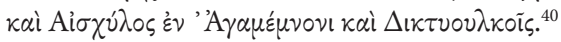

Youngs of the hystriches and similar animals are called obria. And Euripides mentions this term in his Peliades [fr. 616 N], and Aeschylus in his Agamemnon [v. 143] and Dictyulci [fr. 48 N].

Callimachus of Cyrene, the prominent poet of the Alexandrian epoch $\left(4^{\text {th }}-3^{\text {th }}\right.$ cent. B.C. $)$, mentions in his hymn to Artemis the animal called $v \sigma \tau p \xi \xi$; the meaning is unclear:

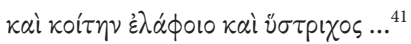

the lair of the stag and where the porcupine hath his burrow ....

In the Polish translation Wiktor Steffen gives the meaning $d z i k$, 'boar', not confirmed by the lexical material of the Ancient, Medieval and Modern Greek ${ }^{42}$. Though the identification is wrong, it should be emphasized that any translation, including 'porcupine', 'hedgehog', 'badger', would be equally arbitrary.

\section{Conclusions.}

The standard dictionaries of the Ancient Greek language usually list three dif-

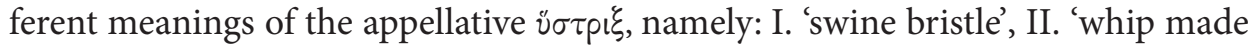

39 Aeschylus, fr. 47 a.

40 Aelian, VII, 47, vol. II, London-Cambridge Mass. 1959 (with my translation; in trans. of A.F. SCHOLFIELD: And the young of porcupines and similar creatures are called ö $\beta \rho \imath$. It is hardly certain that the ṽ $\sigma p \downarrow \chi \varepsilon \varsigma$ denote 'porcupines' in this fragment).

${ }^{41}$ Callimachi Hymni et Epigrammata, H, III, 96, rec. U. von Wilamowitz-MoellendorfF, Berolini 1882, p. 20. See also Callimacho, Inni. Chioma di Berenice, trans. V. Gigante Lanzara, ${ }^{3}$ Milano 1993, p. 32. English translation: Callimachus, Lycophron, Aratus, trans. A.W. Mair, G. R. Mair, Cambridge Mass.-London 1989, p. 69.

${ }^{42}$ Antologia liryki aleksandryjskiej, trans. W. StefFen, Wrocław 1951, p. 16 [= Biblioteka Narodowa, II, 64]. 
of swine leather and bristle', III. 'hard-shelled porcupine'. It is necessary to add as many as three or four new meanings (IV. 'hedgehog', V. 'sea urchin', VI. 'badger'; VII. 'an unclearly defined animal') to the previously established ones.

\begin{abstract}
Dictionaries of the Ancient Greek language distinguish only two or three different meanings of the Greek word $v \sigma \tau p \xi$. The present author analyses all the contexts and glosses where the word in question appears. On the basis of his own analysis he assumes that dictionaries of Ancient Greek should contain as many as seven different semantems: I. 'swine bristle', II. 'swine leather whip, the cat, used as an instrument of punishment', III. 'porcupine, Hystrix cristata L.', IV. 'hedgehog, Erinaceus europaeus L.', V. 'sea urchin', VI. 'badger, Meles meles L.'; VII. 'an unclearly defined animal'.
\end{abstract}

Krzysztof Tomasz Witczak

Zakład Językoznawstwa i Indoeuropeistyki

Wydział Filologiczny

Uniwersytet Łódzki

ul. Lipowa 81, p. 408

90-568 Łódź, Polska

krzysztof.tomasz.witczak@gmail.com

ktw@uni.lodz.pl 